\title{
South Africa's Road to Democracy could have Suffered a Still Birth had it not Been for the Unseen Role Played by Women: Interfacing with the Undercover Operations of Women
}

\section{Peter Masvotore \\ Linda Tsara}

\section{Abstract}

South Africa's road to democracy cannot be complete without the untold stories of the undercover operations played by women during and after the Rivonia arrests. It is a fact that after 1963 the leadership of both organisations namely the African National Congress (ANC), the South African Communist Party (SACP) and Umkhonto We Sizwe (MK) were behind bars. As a result, there was virtually complete destruction of internal leadership of both organisations and the struggle for democracy nearly suffered a still birth had it not been for the untold undercover operations of some women among men who stood firm and courageous to complete the struggle. The story of South Africa's road to democracy cannot be complete without considering the contributions made by women who galvanised and reconstituted political organisations through undercover operations. Using a post- colonial feminist theory this paper seeks to rediscover and reposition the contributions by women such as Albertina Sisulu, Ruth Mompati and Joyce Sikhakhane among others through their undercover operations as complementary efforts to complete the road to democracy. The paper will grapple with questions such as; To what extent could women's underground operations be built, and maintained, in the face of constant police surveillance, and the methods of torture favoured by the Special Branch in particular? What was the nature of the undercover operations that were created? These and other questions are 
explored to rediscover and put women on the map and complete the story for South Africa's road to democracy.

Keywords: South Africa, Democracy, Undercover, Women

\section{Introduction}

The involvement of women in the struggle tends to attract controversy (Suttner 2003). This is mainly related to the extent and character of women's participation in the road to democracy in South Africa. Some men suggest that their activities merely replicate existing patriarchal relations or that women perform unimportant roles while men are praised as heroes. In as much as this article is on undercover operations of women during and after the Rivonia arrests it also relates to individual women who played underground roles in both political and military activities that paved the road to a democratic South Africa. Although there is no doubt that the overt leadership has been dominated by men, the seemingly unacknowledged and informal segment of society controlled by women has been the key to many of the most significant mass movements in modern South African history. While it is only in the very recent past that the crucial role played by women in raising basic issues, organising and involving the masses has become more widely recognised (Bernstein \& Bernstein 2015) there are few publications that put women on the front page of the road to a free South Africa hence the drive to research on this matter to fill the knowledge gap.

According to Houston (2004) in 1963 the leadership of both organisations namely the African National Congress (ANC), the South African Communist Party (SACP) and Umkhonto We Sizwe (MK) were behind bars including the likes of Nelson Mandela, Walter Sisulu ${ }^{1}$ and others. As a result, there was virtually complete destruction of internal leadership of both organisations. According to Mbeki (1992:86) a meeting of the National Executive of the ANC was held by those outside of prison and a decision to declare a day of mourning was reached. It was also resolved that in the event of the government banning the ANC, it would not dissolve. The struggle for

${ }^{1}$ The most significant recent public acknowledgement of membership is that of the late Walter Sisulu, who was at the time a member of the SACP Central Committee. (Cf Elinor Sisulu, 2002: 122 and Walter Sisulu, 2001: 92). 
democracy nearly suffered a still birth had it not been the untold undercover operations of some women among men who stood firm and courageous to rekindle and keep the fire burning as complementary efforts to complete the struggle. A post- colonial feminist theory is used in this article to rediscover and reposition the contributions of some women like Albertina Sisulu, Ruth Mompati and Joyce Sikhakhane among others through their undercover operations as complementary efforts to complete the road to democracy. The paper grapples with answering questions like; To what extent could women's underground operations be built, and maintained, in the face of constant police surveillance, and the methods of torture favoured by the Special Branch in particular? What was the nature of the undercover operations that were created? These and other questions are explored to rediscover and put women on the map and complete the story for South Africa's road to democracy.

\section{Scope of Undercover Operations}

The notion of undercover operations which this article seeks to explore can be understood as underground activities that include both political and military operations that women undertook secretly to augment efforts by men in order to deal with the Apartheid regime and pave the road to democracy in South Africa (Suttner 2003). The focus is not limited to a specific geographical space even though the goal of the writers is purely related to South Africa. Even if the undercover operations have been carried out in Johannesburg the underground phenomenon should be traced also to other forms of support rendered by women during and after the struggle for a democratic space in South Africa.

Another dimension to be mentioned is the formal and informal undercover operation networks that were used by women during the period in question. By informal undercover operations one should note that there are women who constituted and operated in undercover operations using clubs such as sewing clubs and tea parties in disguise. These women also operated in illegal publications and created their own pamphlets or just painted slogans on walls. One such publication was the African National Congress Voice: An Occasional Bulletin, No 1, April 1960. According to Suttner (2005:72) advice to those holding illegal literature and suggestions for security would become characteristic of underground publications over the years. In the bulletin it was declared that: 
We shall continue to work Underground until the unjust and immoral ban suppressing the ANC has been repealed. This bulletin, 'Congress Voice,' will be issued from time to time. Read it. Study it. Pass it on but do not be caught with it, or tell anyone where you got it (Karis \&nd Gerhart 1977:574).

This clearly demonstrates the magnitude of secrecy that was prevailing during execution of duties in the undercover operations.

\section{Methodology}

Having explored the scope of undercover operations and gained its understanding it is proper to look at the literature that covers undercover operations. Written literature that covers this phenomenon in Southern Africa is scarce because of the nature of operations that are executed in secrecy as such it is limited for public consumption. It is even worse when it comes to women's undercover activities. The article has used a desk research methodology. Although efforts to make telephone interviews were done it yielded fruitless results because interviewees were not keen to divulge and share secret information with strangers in the fear that the information may end up in the wrong hands. According to Creswell (2009) a desk research refers to secondary data or that which can be collected without fieldwork. Hakim (1982:1) defines secondary analysis as 'any further analysis of an existing data set which presents interpretations, conclusions or knowledge additional to, or different from, those presented in the first report on the inquiry as a whole and its main results'. In the context of this article the term is widened to include all sources of information that do not involve a field survey. This most certainly will include searching libraries and the internet.

This article has relied much on underground activities recorded in autobiographies such as Jaffer, 2005; Middleton, 1998 Bernstein, 1994 and Suttner, 2005. These works provided archival source of information regarding undercover operations of women in South Africa. Andrews et al. (2012, see also Smith et al., 2011) suggest that in a time where vast amounts of data are being collected and archived by researchers all over the world, the practicality of utilizing existing data for research is becoming more prevalent. Furthermore, desk research analysis is analysis of data that was collected by someone else for another primary purpose. The utilization of this existing data 
provides a viable option for researchers who may have limited time and resources. Desk research analysis is an empirical exercise that applies the same basic research principles as studies utilizing primary data and has steps to be followed just as any research method. It is important to further define secondary data analysis as a systematic research method. Yet, few frameworks are available to guide researchers as they conduct desk research data analysis (Andrews et al. 2012; Smith et al. 2011).

The major advantages associated with desk research analysis are the cost effectiveness and convenience it provides (Dale et al. 1988). Since someone else has already collected the data, the researcher does not have to devote financial resources to the collection of data. Access to this type of data presents opportunities for all researchers, even the novice or unfunded researcher, therefore equalizing opportunities and building capacity for empirical research (Hakim 1982). Doolan and Froelicher (2009) also state that the use of existing data can accelerate the pace of research because some of the most time -consuming steps of a typical research project, such as measurement development and data collection are eliminated. Additionally, in the area of information policy, utilizing existing data can allow the researcher to answer important time-sensitive policy related questions quicker (Magee et al. 2006).

In this article the researchers were at a disadvantage because they did not participate in the execution of the data collection process. In order to address these gaps the researchers utilized documentation from the original studies and information from published sources for a careful reflective examination and critical evaluation of the data as a mitigating measure to avoid most limitations of desk research methodology (Boslaugh 2007; Dale et al. 1988; Kiecolt \& Nathan 1985). The authors of this article are also aware that they might not have access to other documents that could contain useful information on undercover operations of women in South Africa for this article.

\section{Post-Colonial Feminist Theory}

Post -colonial feminism is a discourse that emerged as a critique of the homogenizing tendencies of western feminism ${ }^{2}$ (Mohanty 2003). Furthermore,

${ }^{2}$ Western culture is prevalent worldwide and imposes both the positive feminist ideals and the conflicting negative media messages on third world and developing countries. In this context the impact of Western culture in the 
contrary to western feminism, post -colonial feminist theory is a new wing that aims to illuminate the problems of women of the Global South that mainly includes the initiative of those activists, and academics who belong to fully or partially once colonized countries. By so doing, post- colonial feminists advocate for the emancipation of women from men and from the patriarchal syndrome. Mohanty (2003:24) further argues that post- colonial feminist theory is primarily concerned with the representation of women in once colonized countries and in western locations and it focuses on the construction of gender difference, in the colonial and anti-colonial discourses with particular reference to the work of women.

Tolan (2006: 17) argues that post- colonial feminist theorists struggle against the maiden colonial discourse which aims at misrepresenting women as inferior. Similarly, Peterson and Rutherfold (1986:14) highlight that 'women suffers from double colonization', referring to the ways in which women have simultaneously experienced the oppression of colonialism and patriarchy. The scholars further argue that a woman must resist the control of the colonial power not only as a colonized subject but also as a woman. By so doing, post -colonial feminist theory exerts pressure on the mainstream postcolonial theory in its constant proclamation of the necessity to consider gender issues. A post- colonial feminist theory is used in this article as a lens to rediscover and reposition the contributions made by women through their undercover operations as complementary efforts to complete the road to democracy as will be discussed later in this article.

\section{Women's Position in Society Prior to Undercover Freedom Struggle Operations}

Prior to the armed struggles generally in countries like South Africa and Zimbabwe women were severely oppressed socially, politically and economically (Bernstein \& Bernstein 2015: 48).

specific realm of feminism and female stereotypes globally and this article suggests common goals and difficulties for all women. As a dominant culture, the United States must be aware of the media messages it shares with the rest of the world and the examples it promotes as not all are compliant with other cultures. 
There are general lessons that can be drawn from the empirical data and these lessons apply not only to some of the countries mentioned in this article, but to South Africa itself. It is noted that before revolution, Southern African countries were characterized by a patriarchal system that promoted a male superiority ethic and female inefficacy and inferiority complex (p. 50). Bernstein and Bernstein (2015: 50) further state that 'a woman was expected to provide three services to her husband, (i) sexual pleasure on demand; (ii) Children, especially sons, who will bring wealth in the future; and (iii) Unpaid domestic (and even agricultural) labour'.

The labour performed by women was separated from that of men not by the manual exertion required, but by the status accorded the work. In Zimbabwe for example, women not only performed house-care and child-care duties, but also sowed, weeded and harvested crops and in fact formed the bulk of the labour force (Shoko 2015). But in South Africa women's work was afforded no status and the surplus they produced was appropriated by men. The tribal chiefs and elders usually married several wives in order that they had more labour in the form of women and children to produce more surpluses (Schmidt, 1992). Shoko (2015) indicates that women who did not bear sons were therefore likely to become outcasts. As such marriages were arranged between the elders of the extended families who determined which alliances were most advantageous for their families.

Women's status and rights particularly regarding marriage and family which were previously governed by customary law became victim to the interpretation of settler officials. Though men were regarded as majors in the eyes of the judicial system, women were seen as minors in perpetual tutelage to their guardians (Schmidt 1992). In their struggle women did not lose sight of the fact that meaningful change for them could not come through reforms but only through the destruction of the apartheid system. While women desire their personal liberation, they see the process achievable together as part of the liberation movement. Despite the fact that leadership has been dominated by men, on the face of it the unappreciated and unofficial section of society was controlled by women and it remained the key answer to many of the major mass movements in modern South African history although some of their activities were invisible.

The reason for this 'invisibility' of women, can be explained from the standpoint that South African societies (and this applies in varying degrees to all race groups) are conventionally patriarchal. In other words, it was the men 
who had authority in society; women were subordinate to men. Bernstein and Bernstein (2015:50) state that women's role was primarily a domestic one that involves child rearing and seeing to the well-being, feeding and care of the family. Women were not expected to be concerned with affairs outside the home for this was the preserve of men or rather that was more properly the domain of men. Women could participate in economic activities beyond the home for reasons of helping to feed and clothe the family, but that was not considered 'feminine' jurisdiction. However, with the rise of the industrial economy, the growth of towns and (certainly in the case of indigenous societies) the development of the migrant labour system, these prescriptions on the role of women came to be eliminated.

What, then, was the position of women in South African society at the beginning of the $20^{\text {th }}$ century? The answer is that black women in traditional African societies and similarly, white women in settler society, were subordinate to men. Explained from another perspective as mentioned earlier the position of women was inferior; the men took all the major decisions both in society at large and within the home. In other words, South Africa was and is patriarchal. According to Magwaza (2011), the reason for patriarchal leadership goes back to the Zulu culture where men are the heads of the family and their leadership is natural. Contrary to the argument by Magwaza women today are challenging the status quo and organizations such as 'women forum', Gender for Equity and Ministry of Women and Children Affairs are condemning patriarchal dominance, even though motherhood was women's primary role and they had to look after children, care for the home and see to the needs of the family. Furthermore, in African societies women were expected to undertake agricultural tasks as well as to help feed the family. Others took in laundry to provide extra income while some entered the labour market as domestic workers. In settler society too, it was not considered feminine to work outside the home, although some women did so to supplement the family income and help put food on the table. In current socioeconomic and cultural dynamics there is equity in terms of gender participation in all spheres of societies.

According to Bernstein and Bernstein (2015) men waged and fought wars and constituted the labour force on the mines in the developing cities and the new government set up in 1910 (without consulting any women). If women featured at all it was as victims of man-made wars (such as the victims in the camps). But this does not mean women were not active participants in these 
developments rather their involvement was overshadowed by men and some women chose to operate from undercover such as Albetina Sisulu and others. Women were not expected to be assertive and take matters into their own hands (Bernstein \& Bernstein 2015). Examples to illustrate the subordinate position of women at the beginning of the century is drawn from black women, most of whom were still living in the reserves, who already had begun to form groups to take on some church-linked social roles in the community, but they were not accepted as members of the African National Congress (ANC) when it was formed in 1912, their acceptance only came in 1943 (Bernstein \& Bernstein 2015:52). Furthermore, Bernstein and Bernstein also indicate that:

Black men realized the need to unite politically to form a common front against white oppression, but amazingly there was no place for their women in their plans to do so. Similarly, white South African women were not permitted to play any part in political decisionmaking in a male-run Union government. It was only in 1930 (many years after settler women elsewhere in the empire) that white women gained the vote. This law was only grudgingly passed, by an all-male, all-white parliament, after a concerted 20-year campaign by dedicated feminists (2015:52).

This clearly shows that women were overshadowed by the patriarchal society hence they needed to operate as a unity for emancipation. Although they continue to be downplayed by men their contribution cannot be ignored for without it one could not fully retell the South African history of liberation. Having looked at the general role of women in a patriarchal society it is now prudent to look at their actual participation in undercover operations that helped to resuscitate the structures of the liberation movement of the ANC.

\section{The Role of Women in Actual Undercover Operations}

Looking at the period (1963-1964) of the Rivonia trial the Secretariat of the ANC at national level was functioning, but it repeatedly faced interruptions because its members were being detained and some were leaving the country as testified by Houston (2004: 603). During this time in question the underground movement structures were in their formation stage. Members of this undercover operation (scope and meaning were discussed in the 
paragraphs above) played a low key in its modus operandi but their main achievement was to endure as structures and to continue many of their activities.

One interesting thing to note in this undercover operation was the full involvement of women, especially the wives of those who were in detention. Key figures are noted by Houston when he indicated that:

Albertina Sisulu, Gertrude Shope, Greta Ncaphai, Hunandi Motsoaledi, Irene Mkwayi, Tiny Nokwe, June Mlangeni, Beauty Makgothi, Rita Ndzanga, Eufenia Hlapane and others worked closely with some of the leaders who had not been arrested. These women performed various special roles, such as organising safe accommodation for those who were on the run, finding safe storage for propaganda and publicity equipment, managing an elaborate communications system and courier network for the underground, and undertaking routine political chores such as gathering information about and attending to the welfare of victims of the struggle (Houston 2004: 603; see also Suttner 2005).

Houston further states that the women undercover operation was closely concerned in assisting families of members who had been imprisoned, by making provisions of money for their daily needs (Houston 2004:605). One such undercover operation could take place when activists would also attend the shanty clinic, where Albertina Sisulu worked in Soweto. According to Elinor Sisulu (2002:206, 215) 'while Albertina was taking patients' case histories, they would exchange political information'.

The ANC leadership felt that working conditions in the country necessitated military preparations outside. In the process of recruiting people for the MK in an undercover operation Albertina Sisulu in October 1964 was one woman among many who was probably involved in arranging for people from Soweto to leave the country for military training and for those returning from receiving training to instruct others inside the country (Houston 2004: 605-606). A testimony of a state witness indicates that:

Like most houses in the area, the toilet of Albertina's house adjoined that of Metty's [whose nickname was Gogo Mangongomane] in one outside building at the end of the garden. The wall between the two 
toilets was so thin that one could easily conduct a conversation with the person next door. Albertina's colleagues from The Federation of South African Women (FEDSAW) would pretend to visit Gogo Mantongomane. They would then go to the toilet and have a 'meeting' with Albertina in the toilet next door. Gogo would keep a lookout for the security police while pretending to be busy in her garden (Elinor Sisulu 2002:206).

Such undercover operations cannot be left unnoticed as major contributions by women in the process of reviving the ANC even though its leaders were under custody. The early phase immediately after Rivonia was thus a case of patching together what could be joined, reconnecting with old comrades who were not too afraid to engage in illegal work, especially drawing on the veterans who remained outside of prison or prisoners released after relatively short sentences.

The involvement of women in undercover operations did not arise directly out of a feminist consciousness. According to Bernstein and Bernstein (2015:49):

In a guerrilla war there was no 'front', battles took place wherever there were people. One horrific example is the massacre which took place in Domboshava in Zimbabwe. Domboshava was attacked by security forces on the 10th of June 1978. Of the 22 villagers who were killed, 20 were women and children. Of these, nine were burned to death inside a hut which had been deliberately set alight and eleven were shot dead inside a kitchen. There was no cross-fire at all, and only one guerrilla was killed.

As this example demonstrates, women could normally hardly avoid their involvement in the undercover operations because they had no choice for, they were the victims of circumstances that prevailed during the armed struggle. It is worth noting that the forms of their involvement clearly differed in some respects from one country to the other. The attitudes as to what women's involvement signified also differed.

In South Africa the history of women's involvement in undercover operations does not only begin with the banning of the ANC as a party in 1960 . Their involvement although down played stretches back to the early years of 
the twentieth century when women were among the groups that went for training in Comintern Universities learning undercover methods (Davidson et al. 2003). Women such as Ray Alexander were very active in arranging the hosting of Comintern and the activities of the Communists. When the Communist Party was established in secrecy many women were involved from the onset at various stages of its illegal existence inside and later outside the country as well as in units that later formed after Rivonia (Suttner 2004).

The ANC prepared for the undercover operations from the time of the Communist Party's dissolution in 1950 as they implemented the M-Plan (The Mandela Plan). The crushing of the ANC leadership in Rivonia culminating in the imprisonment and exile left a difficult task for those who remained at large under various restrictions. Women like Albertina Sisulu, Winnie Madikezela Mandela in a separate group, Joyce Sikhakhane, Shantie Naidoo and others were fully involved in the rebuilding of the undercover or underground operations in Soweto (Houston 2004). Houston (2004) further states that in the late 1960s women in the undercover operations provided support for the MK trainees such as Dorothy Nyembe who was later convicted for aiding MK soldiers.

Dingake, 2002) and Houston (2004: 603) states that, Gertrude Shope, for example, was the link between Bram Fischer who was the Communist Party leader, and the ANC underground personnel in Soweto. Houston (2004) further indicates that, Shope was also in charge for receiving money from the Communist Party leadership, in particular through Violet Weinberg, which she would take to ANC and MK leaders based in the African townships. Shope was later also charged with mailing instructions from the ANC leadership in Johannesburg to regional leaders, such as Elijah Loza in Cape Town. Lastly, the Federation of South African Women (FEDSAW), in which she served with national president Albertina Sisulu, played a central role in assisting the families of imprisoned members of the Congress movement (Shope 2001).

In emphasizing the role played by women in undercover operations it is alluded to the fact that in October 1964, Albertina Sisulu organised and arranged for people from Soweto to leave the country for military training, and for those who returned after being trained abroad to train others inside the country (Mandela 1995:483). It was critical during this time that desperate measures were undertaken to involve key figures with fundamental information about the movements in and out of the country before the security police captured them. The security police used torture as a way of extracting 
information from detainees hence their success in capturing undercover syndicate cadres.

It was Fischer who was instrumental in establishing an undercover group of cadres after studying the methods of the Portuguese Communist Party (Frankel 1999:286). Houston (2004:627) argued that a document found in Fischer's possession, entitled 'Notes on the Experience of our Portuguese Branch', dated 12 June 1965, contained plans to reorganise the SACP as a totally secret and undercover entity. According to Houston (2004), the document stipulates that no one could be involved in undercover operations unless all connections with family and friends were disengaged. Engagements should remain for communication purposes, but family members were not supposed to know the false identity or location of undercover operations. Those involved were those with no connections with police, and as soon as they were scrutinized their membership was received or accepted and they were given new identities for disguise. As indicated earlier anyone who was in the undercover operations was to break all ties with family members for the period of operation.

Undercover activities were discouraged from using public transport and organising meetings near their hideouts. Their hiding places were to remain isolated and cadres were only to visit these places when they are sure it was safe to do so. Time was critical as they met in hideouts as such meetings were to last not more than two to three minutes and alternative venues were to be arranged in advance, lest any problems arose regarding the primary meeting place (Houston 2004:26. In the occasion that there was a police raid, each one had to be prepared to tell the police the same cover up story. Illegal or compromising materials were not supposed to be carried to their meeting places in case of a raid by police. Venues for meetings were changed frequently during undercover operations as a disguise method. Only in the most exceptional circumstances should duly authorised Party members have knowledge of the meeting places (Ludi \& Grobbelaar 1966:96-97).

The endeavours to revive all spectrums of undercover operations were done during this period. One of the notable developments of an undercover cell was initiated by Albertina Sisulu and John Nkadimeng, who were residents in Soweto at the time (Sisulu 2002). According to Elinor Sisulu (2002:206), the main activity of this cell 'was to facilitate the passage of ANC members who wanted to leave the country for education or military training'. The cell maintained contact with the ANC leadership in Botswana through a courier, 
Nathaniel Nkosibomvu, and also established links with people in other provinces (p. 207). Albertina Sisulu had been involved in the underground passage of people out of the country in 1964 (Houston 2004:640).

According to Murriel Horrel (1970:64) the trial of Dorothy Nyembe and 11 others took place in the Supreme Court in February and March1969. It was alleged that they had conspired with 26 others to overthrow the existing order in the Republic by means of subversion, terrorism, violent revolution and warfare. Horrel further states that:

Out of the 12, 11 - including Nyembe - were found guilty of various charges under the Terrorism Act, such as going abroad for military training; establishing means whereby those trained could secretly reenter South Africa; searching for suitable submarine landing sites on the coast; inciting people to undergo guerrilla training; and giving assistance to known terrorists (1970:64; see also Houston 2004:641).

It is also believed that Winnie Mandela initiated the establishment of the undercover cell in the Soweto network (Sisulu 2002:215). Sisulu further suggests that Winnie Mandela assumed a leadership role without being authorised to revive the ANC underground. With Mandela and other leaders in prison and Oliver Tambo in exile, a critical question arose over who was to revive the ANC within the country. This is the time when it is assumed Winnie thought that the leadership role was automatically hers. 'I was ready to deputise for Nelson,' she wrote. As Mandela's wife, she was his heir. She had already achieved a high profile of her own. She had spoken on his behalf and on behalf of the organisation. It was only natural that she as a Mandela should assume responsibility (Gilbey 1993:68).

Ruth Mompati also worked undercover as she printed ANC pamphlets with news that calls on people to organise themselves and informing them what was happening and what the leaders were saying from prison. Most of the people who read them were ANC members. That was a way of communicating with people secretly because people had to know (Ndlovu \& Magubane 2001). Ndhlovu and Magubane further state that Ruth Mopati narrates that:

It was very difficult to distribute these pamphlets because they were illegal documents that I had to carry to Soweto. I had to go to a taxi and say: 'Can your taxi move? Let's go'. The driver would ask: 'Where 
to?' I would say: 'Just drive'. You would get to the place and say: 'Stop here'. You would get out. You would go round the corner. You'd bring a box, open the boot, put it in and say: 'You know, if the police find that, it's your problem, not mine'. If I was bringing the pamphlets in the taxi, I would stop the taxi about two houses away from where I was going, take the box, pay the taxi and say: ' $B a b a$, you better move on. You'll get into trouble' (interview 2001)

The other interesting thing was that, when the ANC was banned, the Women's League formed women's clubs that worked in disguise of clubs, but they would do different things (Sisulu 2002:218). Furthermore Sisulu (2002) attests that sometimes meetings were camouflaged as a tea parties or something else. On the other hand Joyce Sikhakhane who was a journalist and was free to move about without attracting too much suspicion, was sought out by political activists, to help them passing messages from one banned person to another, such as Albertina Sisulu and Helen Joseph, and setting up meetings. Toilets in Westgate Station, Faraday Station, were used as meeting places (Gilbey 1993). Sikhakhane got involved in collecting money from the Anglican Church particularly from the Dean of St Mary's Cathedral in Johannesburg, who received monies to be passed on to families of political prisoners (Sisulu 2002). All these activities were done in undercover operations.

\section{Findings and Conclusion}

This article has shown that after the leadership of both organisations namely the African National Congress (ANC), the South African Communist Party (SACP) and Umkhonto We Sizwe (MK) were behind bars there was complete destruction of internal leadership of both organisations and the struggle for democracy nearly suffered a still birth had it not been for the untold undercover operations of some women among men who stood firm and courageous to complete the struggle. The story of South Africa's road to democracy cannot be complete without considering the contributions made by women who galvanised and reconstituted political organisations through undercover operations. This paper has rediscovered and repositions the contributions made by women such as Albertina Sisulu, Ruth Mompati and Joyce Sikhakhane among others through their undercover operations as complementary efforts to complete the road to democracy. 


\section{References}

Andrews, L., A. Higgins, M.W. Andrews \& J.G. Lalor 2012. Classic Grounded Theory to Analyse Secondary Data: Reality and Reflections. The Grounded Theory Review 11,1: 12 - 26.

Bernstein, H. 1994. The Rift. The Exile Experience of South Africans. London: Jonathan Cape.

Bernstein, H. \& R. Bernstein 2015. Women's Role in Third World Liberation Struggles. Johannesburg: Historical Research Archive.

Boslaugh, S. 2007. Secondary Analysis for Public Health: A Practical Guide.

New York, NY: Cambridge. DOI

https://doi.org/10.1017/CBO9780511618802

(Accessed on 11 February 2019.)

Creswell, J.W. 2009. Research Design: Qualitative, Quantitative, and Mixed Methods Approaches. $3^{\text {rd }}$ Edition. Thousand Oaks, CA: Sage.

Dale, A., S. Arbor \& M. Procter 1988. Doing Secondary Analysis. London, UK: Unwin Hyman.

Davidson, A., I. Filatova, V. Gorodnov \& S. Johns (eds.). 2003. The Communist International and South Africa: Documentary History, 1919 1939. Volumes 1 and 2. London: Frank Cass.

Dingake, M. 2002. Email Communication from Dingake to Houston. 7 September 2002.

Doolan, D.M. \& E.S. Froelicher 2009. Using an Existing Data set to Answer

New Research Questions: A Methodological Review. Research and Theory for Nursing Practice: An International Journal 23,3: 203 - 215. DOI: https://doi.org/10.1891/1541-6577.23.3.203

(Accessed on 11 February 2019.)

Frankel, G. 1999. Rivonia's Children: Three Families and the Price of Freedom in South Africa. Johannesburg: Jonathan Ball.

Gilbey, E. 1993. The Lady: The Life and Times of Winnie Mandela. London: Jonathan Cape.

Hakim, C. 1982. Secondary Analysis in Social Research: A Guide to Data Sources and Method Examples. London, UK: George Allen \& Unwin.

Horrell, M. 1970. A Survey of Race Relations in South Africa 1969. Johannesburg: South African Institute of Race Relations.

Houston, G. 2004. The Post-Rivonia ANC/SACP Underground. In The Road to Democracy in South Africa. Volume 1. (1960-1970). Cape Town: 
Zebra Press. (South African Democracy Education Trust.)

Jaffer, Z. 2003. Our Generation. Cape Town: Kwela Books.

Karis, T. \& G.M. Gerhart (eds.). 1977. From Protest to Challenge. A Documentary History of African Politics in South Africa. 1882-1964.

Volume 3. Stanford, California: Hoover Institution Press.

Kiecolt, K.J. \& L.E Nathan 1985. Secondary Analysis of Survey Data.

University Paper Series on Quantitative Applications in the Social Sciences, 53.

https://doi.org/10.4135/9781412985796

Ludi, G. \& B. Grobbelaar 1966. The Amazing Mr. Fischer. Cape Town: Nasionale Boekhandel.

Magee, T., S.M. Lee, K.K. Giuliano \& B. Munro 2006. Generating New

Knowledge from Existing Data: The Use of Large Data Sets for Nursing Research. Nursing Research 55,2: S50 - S56. (Partnerships Advancing Library Media (PALM) Center, Florida State University (2009). School Library Media Specialist and Technology Integration Survey.)

https://doi.org/10.1097/00006199-200603001-00009

Magwaza, T. 2011. Private Transgressions: The Visual Voice of Zulu Woman: Agenda 16,49.

Mandela, N. 1995. Long Walk to Freedom: The Autobiography of Nelson Mandela. London: Bacus.

Mbeki, G. 1992. The Struggle for Liberation in South Africa: A Short History. Cape Town: Mayibuye Centre.

Middleton, J. 1998. Convictions: A Woman Political Prisoner Remembers. Randburg: Ravan Press.

Mohanty, C.T. 2003. Under Western Eyes Revisited: Feminist Solidarity through Anticapitalist Struggles. The University of Chicago Press Journals 28, 2:499 - 535.

https://doi.org/10.1215/9780822384649-010

https://doi.org/10.1086/342914

Moraga, C. 1981/ 1983. In this Bridge Called my Back: Writings by Radical Women of Color. New York: Kitchen Table Women of Color Press.

Ndlovu, S. \& B. Magubane 2001. The Road to Democracy: South Africans Telling their Stories. Vryburg: SADET Oral History Project.

Petersen, K.H. \& A. Rutherfold. 1986. A Double Colonization: Colonial and Post-colonial Women's Writing. Mundelstrup, Denmark; Oxford, England: Dangaroo Press. 
Sisulu, W. 2001. I Will Go Singing. Walter Sisulu Speaks of His life and the Struggle for Freedom in South Africa. In conversation with George M. Houser and Herbert Shore. Robben Island Museum. In Association with the Africa Fund. New York.

Sisulu, E. 2002. Walter \& Albertina Sisulu. In Our Lifetime. Claremont: David Philip Publishers.

Shope, G. 2001. Interview with Gertrude Shope, conducted by Sifiso Ndlovu. 8 May 2001, Soweto, SADET Oral History Project.

Smith, A.K., J.Z. Ayanian, K.E. Covinsky, B.E. Landon, E.P. McCarthy, C.C. Wee \& M.A. Steinman 2011. Conducting High-value Secondary Dataset Analysis: An Introductory Guide and Resources. Journal of General Internal Medicine 28,8: 920 - 929. DOI: https://doi.org/10.1007/s11606010-1621-5 (Accessed on 13 February 2019.)

Snyder, R.C. 2008. What is Third Wave Feminism? A New Directions Essay. The University of Chicago Press Journals 34,1: 175 - 196.

https://doi.org/10.1086/588436

Suttner, R. 2003. Early History of the African National Congress (ANC) Underground: From the M-Plan to Rivonia. South African Historical Journal 49: 123 - 146. https://doi.org/10.1080/02582470308671450

Suttner, S.R. 2005. Rendering Visible: The Underground Organisational Experience of the ANC-led Alliance until 1976. Unpublished Thesis Submitted for the Degree of Doctor of Philosophy. Johannesburg: University of Witwatersrand.

Tolan, P. 2006. Family Violence. Annual Review of Psychology 57: 557 - 583. https://doi.org/10.1146/annurev.psych.57.102904.190110

Peter Masvotore Methodist Minister Zimbabwe masvotorep@gmail.com

Linda Tsara PhD Candidate - African Theology School of Religion, Philosophy and Classics University of KwaZulu-Natal

Pietermaritzburg lindah.tsara@yahoo.com 